\title{
Cell-Free DNA Blood Collection Tube
}

National Cancer Institute

\section{Source}

National Cancer Institute. Cell-Free DNA Blood Collection Tube. NCI Thesaurus. Code C156117.

A proprietary blood collection tube with a formaldehyde-free preservative which stabilizes nucleated blood cells, preventing the release of genomic DNA, and allowing isolation of high-quality cell-free DNA. 